DOI: 10.17707/AgricultForest.61.1.01

\title{
John PAULL \\ GMOS AND ORGANIC AGRICULTURE: SIX LESSONS FROM AUSTRALIA
}

\begin{abstract}
SUMMARY
GMO moratoria are in place in Australia, in some states and not in others. Is co-existence possible between organic farming and GMO farming? And if so, under what circumstances? Australia has more certified organic land than any other country, with a reported 12.0 million hectares of certified organic land compared to the world total of 37.5 million hectares. In a recent court case, an organic farmer lost his organic certification because of GMO contamination. A total of 325 hectares of his 478 hectare farm were contaminated with GM canola blown from a neighbouring property, and this resulted in the decertification of most of the farm. The organic farmer sued his neighbour, a GMO farmer, on the basis of nuisance or negligence, he sought damages for loss of income, and he sought an injunction to rein in his neighbour's future GMO farming practices. The case ran before the Supreme Court of Western Australia over three weeks and it generated more than 1000 pages of transcript. The case was dismissed in its entirety, in a 150 page judgment, and is now subject to an appeal. This paper examines the judgment, in the light of the trial transcript of this landmark case, with the view to determining the implications for the future of organic farming and GMO farming, and in particular to ascertain what lessons can be learned from this litigation.
\end{abstract}

Keywords: Genetically Modified Organisms, Canola, Contamination, Organic Farming, Australia.

\section{INTRODUCTION}

Australia leads the world in terms of agricultural land certified as organic, and it accounts for nearly a third of the world's certified organic agricultural land (Willer \& Lernoud, 2014). Organic agriculture is globally important as a method of "sustainable and environmentally friendly production" (Cukur \& Celik, 2014) and it has evolved to exclude genetically modified organisms (GMOs) from its production systems (Paull, 2014a).

In Australia, the Office of the Gene Technology Regulator (OGTR) "must assess and license a GM [genetically modified] crop before it can be grown commercially in Australia" (DAFF, 2008). Current commercial-release approvals

\footnotetext{
1 John PAULL (corresponding author e-mail: j.paull@utas.edu.au), School of Land \& Food, University of Tasmania, AUSTRALIA.
}

Paper presented at the $5^{\text {th }}$ International Scientific Agricultural Symposium "AGROSYM 2014".

Notes: The authors declare that they have no conflicts of interest. Authorship Form signed online. 
are limited to only GM varieties of cotton and canola (OGTR, 2014). The Regulator must be "satisfied that any risks can be managed to protect the health and safety of people and the environment" (DAFF, 2008).

Australian states and territories have some prerogative in allowing or disallowing GMO crops and, with the exceptions of Queensland and Northern Territory, all states and territories have imposed some level of moratorium on the planting of GMO crops (DoA, 2008). Tasmania and South Australia maintain robust moratoria against GMOs, while Victoria, New South Wales (NSW) and Western Australia (WA) allow GM canola.

According to the Department of Agriculture, Fisheries and Forestry: "Growers planting GM canola are required by the technology provider to undertake stewardship training to enable the co-existence of GM and non-GM canola" (DAFF, 2008). Of concerns about the coexistence of GMO agriculture with the organic sector: "ABARE found that GM canola production will have little if any effect on the organic sector" (DAFF, 2008).

In 2003, WA passed the Genetically Modified Crops Free Areas Act 2003 (Calcutt, 2009). In 2008, WA exempted GM cotton in the Ord River Irrigation Area (ORIA) from the moratorium (WADAF, 2010). In January 2010, WA exempted GM canola from the moratorium despite that "since the advent of GM canola in Canada farmers can no longer grow organic canola in Western Canada" (WADAF, 2010) and declared that "common law allows for effective remedies for persons incurring damage from GM crops" (p.3).

Stephen Marsh and Michael Baxter have adjacent farms (Eagle Rest of 478 hectares and Sevenoaks of 700 hectares, respectively) in the Kojonup region of WA, about $256 \mathrm{~km}$ south east of the state capital city of Perth. Marsh's farm is certified organic by the National Association for Sustainable Agriculture, Australia (NASAA). His neighbour, Baxter, farms chemically and took advice of an agronomist employed by Farmanco, a rural advisory company (Martin, 2014).

Shortly after the moratorium was lifted for GM canola in WA, Farmanco Facts stated that: "The health, safety and environmental risks of adopting GM crops have been dealt with by the Office of the Gene Technology Regulator ... Production and economic risks of adopting the GMO lies with the producer" (Pritchard \& Trezise, 2010). Adopters of Monsanto's GM canola were to "Complete a Technology User Agreement (TUA) including PRAMOG (paddock risk assessment and management option guide)". The TUA requires "a minimum five metre $(5 \mathrm{~m})$ separation between GM and non-GM crops". The transfer of GM material into a neighbour's field was anticipated by Farmanco in that initial advisory: "Where your GM crop is on a boundary fence you will need to discuss management options for this scenario and also for the possibility of strong winds moving swaths into your own and your neighbour's paddocks" (Pritchard \& Trezise, 2010).

In that first year of legalisation in WA, Baxter planted out his paddocks adjacent to Marsh with Monsanto's Roundup Ready canola which was genetically engineered to be resistant to the herbicide glyphosate (marketed by 
Monsanto as Roundup) using genes from bacteria. Marsh had previously alerted Baxter to his concerns that GMO contamination from Baxter's GMO crop may put his organic certification in jeopardy (Martin, 2014).

In late November and early December 2010 Marsh discovered GM canola swathes (Paull, 2014b) in some of his paddocks to a distance of $1.2 \mathrm{~km}$ into his farm; this was reported to his organic certifier and subsequently most of his farm was decertified (Martin, 2014).

Marsh sued his neighbour claiming common law negligence or private nuisance, he sought damages for loss of income, and an injunction to curtail his neighbour's GMO farming practices. The case was heard over the three weeks of 10-28 February 2014 and the judgment was delivered on 28 May 2014. The case was dismissed in its entirety. Organic certification was reinstated over the Marsh farm in October 2013. This case is the most expensive mounted to date by the organics sector, and this paper examines what lessons may be learned from it.

\section{MATERIAL AND METHODS}

The Marsh v. Baxter case generated a substantial corpus of paperwork including the trial bundle (over 3000 pages), the trial transcript (over 1000 pages), and the judgment (150 pages). There was a general consensus about the facts of the case and the present paper draws particularly on the judgment to reveal what lessons can be drawn from the case. The present account is informed by a site visit to the Kojonup region and the road forming the common boundary of the Marsh and Baxter farms, by personal attendance for some days of the trial, and by informal encounters with the parties and their legal representatives at the Supreme Court of WA.

\section{RESULTS AND DISCUSSION}

\section{Contamination}

The judge wrote of "the airborne incursion of approximately 245 GM canola swathes, which I have found were blown into some Eagle Rest paddocks from Sevenoaks in late November or early December 2010". Marsh described this as GMO "contamination" of his farm and so did his organic certifier. The media of various persuasions also characterised this event as "contamination" (e.g. Crothers, 2014; Hamlyn \& Trigger, 2014; Jones, 2011; Peckham, 2014) although Forbes proclaimed "No Such Thing As GMO Contamination' Rules Australian Court in Landmark Decision, Rebuffing Organic Activists" (Entine, 2014).

While finding that the Marsh organic farm had been peppered with GM canola from Baxter's farm, the judge however did not accept that this amounted to "contamination". He wrote of "the late November/early December 2010 airborne incursion of GM canola swathes into Eagle Rest (described by the Marshes in their pleadings and submissions in tendentious fashion as a 'contamination')" (Martin, 2014). The judge declared that: "Much of the difficulty ... (... for Mr Marsh) seemed to stem from the fact that the term 
'contamination' is not defined in the National Standards or in the NASAA standards" (Martin, 2014).

Marsh v. Baxter failed to get to first base in convincing the judge that there had been a 'contamination' of the organic farm, and this was likely fatal for a determination of either negligence or nuisance. There being an agreed "incursion" but not an agreed "contamination" the judge suggested that Marsh should take the matter up with his certifier (and outside of the present action) (Martin, 2014).

Lesson 1: Agree the terms underpinning an action, or produce substantiated definitions.

\section{Mitigation}

The judge commented unfavorably on the fact that the offending GM canola swathes arrived at Eagle Rest from November 2010 but were not removed until April 2011. There is a general principle in law that an injured party ought to act in a timely manner to mitigate the loss incurred from a harm.

The Judgment states that: "Surprisingly, it appears to have taken Mr Marsh until April 2011 to gather up and remove all the swathes and their (attached) canola seed pods. The gathered swathes then filled two drums ... But between late November 2010 to April 2011, the swathes just appear to have been left in situ, whilst photographed, plotted and even fenced off. Surprisingly, nothing timeous happened about getting rid of them, so as to inhibit any wider dispersal of canola seeds from their shattered seed pods across Eagle Rest's paddocks. In this period the 245 swathes appear to have been rather afforded the status of infamous celebrities ... and then made the subject of media releases ... Asked in cross-examination why it took so long to gather up and remove the canola swathes, Mr Marsh, I thought, gave a very unconvincing response for the inertia. He said that he had been 'too busy' ... Part of what supposedly occupied his time appears to have been issuing media statements in liaison with NASAA. That is hardly an acceptable explanation. If there was a serious incursion problem of GM material at Eagle Rest to be dealt with, as Mr Marsh evidently felt there was, clearly it ought to have been addressed immediately, as a matter of high priority, rather than the swathes just being left to blow around in the paddocks of Eagle Rest for a period of about five months" (Martin, 2014).

Lesson 2: Mitigate losses as a priority and be seen to do so rather than to publicise them.

\section{Dispute resolution}

Invoking the apparatus of the law to resolve a business dispute - a civil matter - is wisely regarded as an action of last resort, for at least three reasons: (a) the cost; (b) the locus of control is shifted to a third party; and (c) the law is an adversarial process which produces win/lose outcomes. The outcome is somewhat 
unpredictable and is outside of the control of the parties. In contrast, dispute resolution via negotiation or mediation offers the potential of a win/win outcome, and win/win outcomes are the raison d'être and the everyday currency of business. Tradeoffs are made until a transaction materialises where, for example, for the trader the cash is more valued than the goods and for the purchaser the goods are more valued than the cash.

In Marsh v. Baxter the amount raised by the plaintiffs for the action is stated to be AU\$750,000 (c.€535,000) (Kinnear, 2014) whereas in contrast " $\$ 85,000$ [c. $€ 60,000]$ is the agreed figure for the net loss $\ldots$ arising by reason of the absence of NASAA certification ... for approximately $70 \%$ of the area of the Eagle Rest farm - assuming that liability at this trial is ultimately established against Mr Baxter. That agreed sum has been derived as losses claimed across three successive financial years up to 30 June 2013, by the Marsh farming partnership" (Martin, 2014).

The judge comments on the lack of proportionality between the loss claimed and the potential cost of the recovery: "the $\$ 85,000$ damages claimed is, in the context of the costs of Supreme Court litigation these days, a demonstrably uneconomic amount of money to be litigating over" (Martin, 2014).

Lesson 3: If the principle is more important than the money then 'go for it', otherwise consider the proportionality between the known loss versus the unknown cost of the recovery along with the uncertain surety of any recovery.

\section{Injunction}

Given the obvious discrepancy between the damages sought and the cost of mounting an action in the Supreme Court the judge observed that "For the present action, a perpetual injunction is the significant remedy that is claimed against Mr Baxter" (Martin, 2014). "Injunctions are orders given by a court requiring a party to refrain from performing an action” (Saligari, 2013).

The injunction sought was a cornerstone of the case, it was the significant remedy claimed, and, that being the case, one might expect that the terms of the sought injunction would be clearly stated. Despite such an expectation, the terms of the sought injunction were in a continuous state of flux right up to "the last breath" of the trial (Martin, 2014).

Originally sought was a permanent injunction against the planting of GM canola within $2 \mathrm{~km}$ of the Marsh farm. In the course of the trial this proposed injuncted distance fluctuated until finally being relinquished entirely as was any injuncted planting of GM canola. The various iterations of the 'strong' anti-GMO injunction eventually evaporated to be substituted with a 'weak' anti-GMO injunction that only sought to restrain the method of harvesting (swathing) and only in paddocks adjacent to the Marsh farm. It was a muddled retreat, and even a victory (had there been one) would in these final terms have delivered only an eviscerated shadow of the original.

The judgment relates: "The linear dimensions of the area of permanent 
restraint as sought ... had shrunk considerably in the period prior to trial ... the plaintiff ... sought permanent restraints against planting GM canola against $\mathrm{Mr}$ Baxter on the cascading descent basis of within $2 \mathrm{~km}$, alternatively $1.5 \mathrm{~km}$, alternatively $1.1 \mathrm{~km}$ of Eagle Rest. A permanent restraint was also sought against swathing on an unlimited basis but, in the alternative ... it was sought that $\mathrm{Mr}$ Baxter be permanently restrained from swathing GM canola ... on the same alternative descending basis ranging between $2 \mathrm{~km}$ to $1.1 \mathrm{~km}$ " (Martin, 2014). There was no empirical substantiation: "in this trial the plaintiffs led no expert evidence concerning any underlying empirical basis for buffer zone restraints at any distance from Eagle Rest" (Martin, 2014).

The judge comments on the indeterminacy and vacillation of the plaintiffs: "Fluctuations by the plaintiffs over buffer zone distances, as regards inhibiting swathing on Sevenoaks carry ... a revealing insight for ... what was, or was not, reasonable conduct by $\mathrm{Mr}$ Baxter in November 2010 as regards his swathing ... More than three years after the 2010 incident, the plaintiffs plainly struggle to identify and to set down any fixed linear buffer distance. They finally reach a point where in the last breath of trial they seek a permanent injunction against swathing of GM canola in the (eastern) boundary paddocks of Sevenoaks." (Martin, 2014).

The judge delivered his coup de grace: "In circumstances where a court is asked to exercise a discretion to grant permanent injunctive relief, the absence of an empirical basis to support any buffer distance sought (in perpetuity) is a negative consideration of some moment" (Martin, 2014).

Lesson 4: When seeking to limit other's actions have well substantiated reasons.

\section{Novelty}

Despite the fact that Baxter's own agronomic advisory company, Farmanco, had alerted farmers in their Farmanco News to the risk of GM canola swaths blowing onto neighboring properties (Pritchard \& Trezise, 2010) the judge saw novelty as an excuse for Baxter.

The judgment states: "Given that growing novelty for GM canola in WA, there was necessarily a certain amount of initial learning associated with the first planting, nurturing and then harvesting such a GM canola crop. Although $\mathrm{Mr}$ Baxter had grown canola crops for approximately 10 years before 2010, he had never harvested any of these crops by swathing ... it should be fairly recognised that there was something of an unknown position ... as the first commercial GM canola crops were planted, then harvested by farmers" (Martin, 2014).

Novelty ultimately trumped negligence in the judge's determination: "the common law duty of care as contended for by the Marshes ... is conceptually misconceived and cannot be made out. This is for many reasons. Not the least is, in a wholly novel case, the absence of a duty of care to avoid a foreseeable economic loss" (Martin, 2014). 
Lesson 5: Novelty may support a defence against negligence.

\section{Nuisance}

The events precipitating this court case were a nuisance to Marsh in any common usage of the word. However "there is a difference between what is annoying and what is legally classed as a 'nuisance' ... Private nuisance ... is essentially a dispute between two individuals ... It is enough to show that you have been affected by some act or omission of another person. The effect must be that your enjoyment and use of your land has been interfered with ... you must show that the nuisance complained of is not trivial or unreasonable ... Examples of interference that have been found to be private nuisances include: noisy animals, loud air-conditioners, smoke, overhanging tree branches, tree roots growing into neighbours' land and interfering with drainage, vibrations and dust" (Saligari, 2013).

The judge quoted Pullin that: "Nuisance is a cause of action directed at the harm caused ... proof of nuisance does not involve a failure to exercise reasonable care" (Martin, 2014). The judge observed that a determination of nuisance is about balancing "the right of Mr Baxter to commercially utilise his rural land against the rights of his neighbours, Mr and Mrs Marsh, not to be unreasonably interfered with in their enjoyment and use of Eagle Rest" (Martin, 2014). He found that 'there was no unreasonable interference with the Marshes' enjoyment of Eagle Rest" (Martin, 2014). He argued that: "there was no physical damage from the 245 swathes to persons, animals, land or chattels at Eagle Rest. The character of the damage contended for by the Marshes is purely financial, arising out of a private contractual relationship the Marshes voluntarily entered into with ... an organic status certifying organisation" (Martin, 2014). So despite the low hurdles to jump to establish nuisance, in this case they were not low enough.

Lesson 6: Nuisance may be in the eye of the beholder.

\section{CONCLUSIONS}

This case has provided no assurance that organic farming and GMO farming can happily coexist under the current legal framework. The organic farmer in the case has regained his organic certification after a three year decertification, but there is no constraint on GM farmers to contain their crops within their boundaries, and no recognition in the case that GM crops are a source of contamination for organic farmers. As for the decertification, the judge suggested that the plaintiff take it up with his certifier and seek relief in that direction, rather than from the farmer of the errant GM canola. There was no recognition of the special interests of organic farmers, and a rejection of the notion that wind-blown GM canola plants landing on an organic farm are in any way 'contamination', nor that the neighbour's actions that led to the 'incursion' of the GM plants are either a matter of private nuisance or of common law 
negligence. The matter is subject to an appeal and so there is a faint hope that some or all of the judgment may be reversed.

\section{REFERENCES}

Calcutt, G. (2009). Genetically Modified Crops Free Areas Act 2003, Report on the Review of the Act under Section 19. Perth: Western Australia Department of Agriculture and Food.

Crothers, L. (2014). GM Farmer Wins Landmark Canola Contamination Case. Gain Report, Number AS1414(30 May), 1-4.

Cukur, F., \& Celik, O. (2014). Organic olive farming and its future: A case study from Turkey. Agriculture \& Forestry, 60(4), 199-206.

DAFF. (2008). Biotechnology briefs: Genetically modified crops. Canberra: Department of Agriculture, Fisheries and Forestry (DAFF).

DoA. (2008). Genetically Modified Crop fact sheet. Canberra: Australian Government Department of Agriculture (DoA). www.daff.gov.au

Entine, J. (2014). 'No Such Thing As GMO Contamination' Rules Australian Court in Landmark Decision, Rebuffing Organic Activists. Forbes (www.forbes.com), 28 May.

Hamlyn, C., \& Trigger, R. (2014). GM farmer wins landmark canola contamination case in WA Supreme Court. ABC News (www.abc.net), 14 June.

Jones, L. (2011). WA farmer sues over GM contamination. The Sydney Morning Herald (news.smh.com.au), 28 July.

Kinnear, S. (2014). Steve Marsh case fundraising update. Fundraising update, 16 February. Melbourne: Safe Food Foundation (www.safefoodfoundation.org).

Martin, K. (2014). Judgment: MARSH -v- BAXTER [2014] - WASC 187BC201302729; CIV 1561/2012. Perth: Supreme Court of Western Australia.

OGTR. (2014). Table of applications and authorisations for Dealings involving Intentional Release (DIR) into the environment. Canberra: Office of the Gene Technology Regulator (OGTR). www.ogtr.gov.au

Paull, J. (2014a). Lord Northbourne, the man who invented organic farming, a biography. Journal of Organic Systems, 9(1), 31-53.

Paull, J. (2014b). Organic versus GMO farming: Contamination, what contamination? Journal of Organic Systems, 9(1), 2-4.

Peckham, C. (2014). Australian organic farmer loses landmark GMO contamination case. Reuters (www.reuters.com), 28 May.

Pritchard, B., \& Trezise, T. (2010). GM Canola. Farmanco News, 30(2), 6-10.

Saligari, N. (Ed.). (2013). The Law Handbook 2014. Melbourne: Fitzroy Legal Service.

WADAF. (2010). Organic farming and genetically modified crops. Perth: Western Australia Department of Agriculture and Food (WADAF).

Willer, H., \& Lernoud, J. (Eds.). (2014). The World of Organic Agriculture: Statistics and Emerging Trends 2014: Frick, Switzerland: Research Institute of Organic Agriculture (FiBL) \& Bonn: International Federation of Organic Agriculture Movements (IFOAM). 